\section{International Scientific Journal Theoretical \& Applied Science}

\author{
p-ISSN: 2308-4944 (print) e-ISSN: 2409-0085 (online) \\ Year: $2016 \quad$ Issue: 2 Volume: 34 \\ Published: 29.02.2016 http://T-Science.org
}

Eugene Vasil'evna Vinogradova Associate Professor, Candidate of Philosophycal Science, Assistant professor Department of History and Philosophy, State Maritime University Admiral Ushakov, Russia, grape3@yandex.ru

SECTION 30. Philosophy.

\title{
AESTHETIC VIEWS E.TRUBETSKOGO
}

Abstract: The article raises the question of ethical views E.Trubetskogo Russian religious philosophers of the Silver Age, lawyer and public figure, who had a huge influence on the spiritual B situation is the beginning of the 20th century, knowledge of the world connects man with his attitude to the world map of the world on the law of truth, Goodness, and Beauty.

Key words: holistic, chaste, a person, a thinker, patriotic faith.

Language: Russian

Citation: Vinogradova EV (2016) AESTHETIC VIEWS E.TRUBETSKOGO. ISJ Theoretical \& Applied Science, 02 (34): 143-151.

Soi: http://s-o-i.org/1.1/TAS-02-34-19 Doi: crossef http://dx.doi.org/10.15863/TAS.2016.02.34.19

УДК 1:3+930.1

\section{ЭСТЕТИЧЕСКИЕ ВОЗЗРЕНИЯ Е.Н.ТРУБЕЩКОГО}

Аннотация: В статье поднимается вопрос об эстетических воззрениях Е.Трубецкого русского религиозного философа Серебряного века, правоведа и общественного деятеля, оказавшего огромное влияние на духовную ситуачию начала 20 века, связывавшего познание мира человеком с его отношением к миру, отображением этого мира по законам Истины, Добра и Красотыл.

Ключевые слова: цүелостный, целомудренный, личность, мыслитель, патриотичесность веры.

Князь Евгений Николаевич Трубецкой (1863-1920) - русский религиозный философ Серебряного века, правовед и общественный деятель, оказавший огромное влияние на духовную ситуацию начала 20 века. Его идеи оказали значительное влияние на последующее развитие русской философии. Будучи либералом по своим взглядам и активно участвуя в либеральных и антимаксималистских позиций, попав в сложную ситуацию реалий российской действительности, свою деятельность он рассматривает в качестве нравственного долга. Такой целостной целомудренной личностью предстал перед нами русский мыслитель философ князь Евгений Николаевич Трубецкой.

В эстетических воззрениях Е.Трубецкого прослеживается традиция русского православного философствования, русского осмысления мира, жизни человека. Эта традиция, связывающая познание мира человеком с его отношением к миру, отображением этого мира по законам Истины, Добра и Красоты. Ибо мир, по В.Соловьеву (а Соловьев можно сказать, был «духовным отцом» братьев кн.Трубецких) есть единство материального, духовного и божественного. И человек с помощью разума способен воспринимать божественную премудрость и преобразовывать мир по законам Истины, Добра и Красоты. Так же, как и Соловьев, Е.Трубецкой, в своем творчестве исходит из этой триады, что идея есть вместе с тем и величайшим добро, и высочайшая истина, и совершеннейшая красота.

В работах «Три очерка о русской иконе» и в «Умозрении в красках» Трубецкой видит в русских иконах нечто такое, что позволяет ему сказать об иконе как о «знамени нации» и о «наивысшем ее выражении». На иконах Христа его внимательный взгляд узнает «типичные черты русского лица», и русская нация, по Трубецкому, самодостаточна, не нуждается ни в чьем водительстве, сама способна «осветить мир». Здесь он как бы отстаивает «русский национализм». Но это не совсем верно. Трубецкой приводит пример о готике, как особом виде искусства, принадлежащем сначала немцам, 
потом англичанам, французам как основание «патриотической веры», ну а русские как бы следовали их примеру. И здесь Е.Трубецкой защищает русскую культуру, русскую живопись, говорит об эстетическом превосходстве иконы над западной живописью, которая проистекает, по Трубецкому, из религиозного превосходства православия над латинством» [3. - С.157] К этой мысли Трубецкого можно относиться поразному. Но несомненной заслугой Е.Трубецкого является то, что он увидел в иконе не только и не столько эстетический феномен, но и феномен нравственного и религиозного сознания русского народа, своего рода «ключ» к загадкам и тайнам русского «национального самосознания».[9. C.442] Древние русичи - не философы, а «духовидцы» выражали свое отношение к миру, по Трубецкому, не в мыслях, не в словах, а в красках, но их живопись отвечает на главный вопрос и нашей жизни: для чего мы живем? И в те далекие времена Русь терзали бесчисленные орды. Звериное царство и тогда приступало к народам с извечным искушением: «все сие дам тебе, всегда поклонившися мне» [3. - С.327].

И это древнерусское искусство зародилось в борьбе с этим искушением. Иконописцы древнерусские, по мнению Е.Трубецкого, с поразительной силой и ясностью воплотили в образах и красках то, что наполняло их душу видение особой жизненной правды и иного смысла мира через несравненного языка религиозных символов» [3. - С.327] Таким важным символом в иконописном изображении становится понятие храма. Именно храм понимается как начало, которое должно господствовать в мире. Именно сама вселенная должна стать храмом Божьим. Именно в идее мирообъемлющего храма, по Трубецкому, заключается та религиозная надежда на грядущее умиротворение всей твари, которое то и противопоставляется факту всеобщей войны и всеобщей кровавой смуты. И эта тема весьма явно прослеживается в древнерусском религиозном искусстве. [3. - С.327] Но эта идея «мирообъемлющего храма» и по настоящее время выступает как идеал, ибо мы живем, по Трубецкому, пока вне этого храма.

В природном же (зверином) мире действуют слепые, бессознательные силы. И жизнь человечества напоминает нам животный мир, в котором выживает тот, кто обладает «техникой орудий истребления» и демонстрирует нам отсутствие духовной жизни. [3. - С.325] В мирное время в обществе это «роковое сходство скрыто, «замазано» культурой». В дни же вооруженной борьбы народов оно выступает с «цинической откровенностью». И более того, оно не затемняется, a, наоборот, подчеркивается культурой. И в дни войны самая культура становится орудием злой, хищной жизни и выступает в сущности в той же роли как челюсти и зубы зверей. И принципы, управляющие жизнью человечества, уподобляются тем законам, которые влавствуют в животном мире. Такие правила, как «горе побежденным» и «у кого сильнее челюсть, тот и прав», которые и в наши дни провозглашаются как руководящие начала жизни народов, суть не более и не менее как возведенные в принципы биологические законы. [3. - С.325] И далее Трубецкой подчеркивает, что это превращение законов природы в принципы - в этом возведении биологической необходимости в этическое начало - сказывается существенное различие между миром животным и человеческим, различие не в пользу человека. [3. - С.325] Ибо в человеческом мире военная техника - всецело изобретение человеческого ума. И целые народы все свои помыслы сосредоточивают на этой одной цели - создания «больших челюстей» для сокрушения и пожирания других народов. И порабощение человеческого духа низшим материальным влечением ни в чем не сказывается так сильно, как в господстве этой одной цели над жизнью человечества господство, которое неизбежно принимает характер принудительный. И когда появляется на мировой арене, по Трубецкому, какой нибудь народ - хищник, который отдает все силы технике истребления, все остальные в целях самообороны вынуждены ему подражать, чтобы не «рисковать быть съеденными милитаристами». Эта мысль Трубецкого, его рассуждения, высказанные в начале XX в., в период I Мировой войны, не утратили своей актуальности и поныне. Так, уже в начале XXI века США, Североатлантический блок, НАТО обнаруживают свою звериную сущность и навязывает миру посредством современной техники свой миропорядок, не считаясь с желаниями и чаяниями народов мира.

И тот звериный образ, звериный оскал продолжает довлеть и над современным человечеством.

И падение человека, по Трубецкому, заключается в искажении человеческого облина. Даже потоки крови, наводняющие вселенную, представляют собой меньшее зло, по сравнению с этим искажением человеческого облика [3. C.326] Все эти реалии современной жизни, с необычайной силой ставят вопрос, который всегда был основным для человека - вопрос о смысле жизни. И, естественно, чем ярче выступают в жизни те злые силы, которые стремятся утвердить в мире кровавый порядок и бессмыслицу, тем ощутимее становится понятным необходимость отыскания этого смысла жизни. В кровавом месиве войны, увы, 
обнаружить смысл и ценность человеческой жизни нельзя! Вот почему вслед за статьями «Умозрение в красках» и «Два мира в древнерусской иконописи» появляется фундаментальный труд Е.Трубецкого «Смысл жизни».

«А пока, пишет Трубецкой, в мире царствует ад с одобрения и согласия человека. Народы живьем глотают друг друга: народ, вооруженный для всеобщего истребления - вот тот идеал, который периодически торжествует в истории. И всякий раз его торжество возвещается одним и тем же гимном в честь победителя - «кто подобен зверю сему!» [3. - С.326]

Во II главе работы «Умозрение в красках» Е.Трубецкой восхищается самим православным храмом, главами храмов в виде купола-луковицы, которая, по Трубецкому, воплощает в себе идею «глубокого молитвенного горения к небесам». В отличие от русского храма византийский купол над храмом изображает свод небесный, покрывающий землю. Готический шпиц, напротив, выражает собою неудержимое стремление ввысь, подъемлющее к небу от земли каменные громады. А вот глядя на наш московский Иван-Великий, кажется, что мы имеет перед собою как бы гигантскую свечу, горящую в небе над Москвою. И Трубецкой видит в луковице ее религиозно-эстетическое значение в нашей церковной архитектуре потому, что она именно оказывает эстетическое впечатление, соответственно определенному религиозному настроению, ибо они (луковицы) согласно народным выражениям «жаром горят». [3. - С.329] И этот небесный свод как бы говорит нам, что высшее не достигнуто и для достижения его нужен новый подъем духа.

Трубецкой говорит, что между наружным и внутренним сторонами храма существует полное соответствие, ибо видимое снаружи горение неба сходит на землю и покрывается «рукой Всевышнего, благославляющей из темно-синего неба. И эта рука, побеждающая мирскую рознь, все приводящая к единству соборного целого, держит в себе судьбы людские» [3. - С.330] И во храме, таким образом, утверждается то внутреннее соборное объединение, которое должно, по мнению Трубецкого, победить хаотическое разделение и вражду мира и человечества. И это будет «Собор всей твари», как грядущий мир вселенной». Идея была выражена святым земли русской Сергием Радонежским, поставившим храм Святой Троицы. Идеалом Св.Сергия и было преображение вселенной по образу и подобию Св.Троицы, то есть, подчеркивает Трубецкой, внутреннее объединение всех существ в Боге. И этим идеалом вдохновлялось все древнерусское благочестие, им же жила русская иконопись» [3. -
C.331] Главная тема всей древнерусской живописи, по Трубецкому, подчинена идее преодоления ненавистного разделения мира и преображения вселенной во храм. «Нет ни малейшего сомнения, - пишет Трубецкой, - в том, что эта иконопись выражает собой глубочайшее, что есть в древнерусской культуре; более того, мы имеем в ней одно из величайших, мировых сокровищ религиозного искусства» [2. - С.331]

Долгое время даже образованные русские люди довольно равнодушно относились к иконе, хотя бы уже потому, что они были покрыты слоем копоти, выглядели тускло. Но после того, как была изобретена техника очистки икон, перед изумленным человечеством открылись чудесные краски, и икона предстала как одна из самых красочных созданий живописи всех веков, с их удивительной «изумительной» жизнерадостностью. Но, к сожалению, с этим незнанием нашим красок древней иконописи обнаружилось и «полнейшее непонимание ее духа». [3. - С.331] Обращалось внимание на некий аскетизм икон. Е.Трубецкой говорит, что этот аскетизм сочетается с необычайно живыми красками для выражения и высшей скорби, и высшей радости. Открыть тайну этого сочетания можно лишь после того, как отыщешь ответ на вопрос о смысле жизни, которое воплотилось в древней иконописи. При этом Трубецкой подчеркивает, что в нашей иконописи радостные и скорбные, аскетические мотивы одинаково необходимы. Более того, замечает автор, этот скорбно-аскетический аспект здесь имеет подчиненное и притом подготовительное значение. Но важнейшее в ней - это «радость окончательной победы Богочеловека над зверочеловеком, введение во храм всего человечества и всей твари; но, говорит Трубецкой, - к этой радости человек должен быть подготовлен подвигом, ибо он не может войти в состав Божьего храма таким, каким есть, потому что «для необрезанного сердца и для разжиревшей, самодовлеющей плоти в этом храме нет места: и вот почему иконы нельзя писать с живых людей». [3. - С.333] Ибо икона не портрет, а прообраз грядущего храмового человечества. Но пока этого человечества мы не видим в нынешних грешных людях, а только угадываем, икона, говорит Трубецкой, - может служить лишь символическим его изображением. И истонченная телесность есть не что иное, как резко выраженное отрицание того биологизма, который возводит насыщение плоти в высшую и безусловную заповедь. Е.Трубецкой говорит о чувстве острой тошноты, которое он испытал, когда попал в Эрмитаж на выставку рубенсовской живописи. «Рубенсовские вакханалии» тотчас объяснили ему то самое свойство икон, как святость и аскетизм. 
«Вакханалия - пишет он, - и есть крайнее олицетворение той жизни, которая отталкивается иконой. Разжиревшая трясущаяся плоть, которая услаждается собою, жрет и непременно убивает, чтобы пожирать, - это то самое, чему прежде всего преграждают путь благословляющие персты». [3. - С.340]

Более того, эти персты требуют от нас, чтобы мы оставили за порогом и всякую пошлость житейскую, «житейские попечения», которые утверждают господство сытой плоти» [3. - С.340] И это господство сытой плоти оправдывает право каждого данного народа на кровавую расправу с другими народами, препятствующими его насыщению. Изможденные лики святых на иконах, по мнению Е.Трубецкого, - противополагают этому кровавому царству самодовлеющей и сытой плоти не только «истонченные чувства», но прежде всего - новую норму жизненных отношений, ибо это то царство, которого плоть и кровь не наследует. [3. - С.333] И эта мысль о том, что человечество на данном этапе находится еще в «зверином царстве» своего развития. Так в статье «Звериное царство и грядущее возрождение России», написанной Трубецким в 1919 г. пишет, что «человек не есть высшее в мире существо. Он выражает не только конец, куда мы стремимся, а только серединную ступень мирового подъема. И вот оказывается, что на этой серединной ступени остановиться нельзя. Человек должен сочетаться с Богом или со зверем». Серединного пути нет. «Все народы мира должны решить ясно и определенно, к которой из двух они хотят принадлежать. И тот путь «звериного царства», куда большевизм увлекает мир, есть путь смерти. А тот путь, куда теперь поворачивается русское народное самосознание, есть путь воскресения. В этом и есть, по мысли Трубецкого, то освобождающее слово, которое должно спасти Россию, а с ней вместе все народы мира. [4. См.Кубань. 1991, № 2. C.68]

То угасание духа, которое наблюдал Е.Трубецкой на рубеже XIX и XX вв., видели и другие представители русской православнорелигиозной философии - Соловьев, Бердяев, Булгаков, Федотов, Лосский и др. Они видели в этом большую угрозу для существования цивилизации. Они понимали, что быстрый рост материальной культуры усыплял духовную жизнь общества. Поклонение «золотому тельцу, отмечает Е.Трубецкой, породило между людьми взаимную ненависть и вызывало войны. А зависть и вражда отдали человечество во власть «зверя, выходящего из бездны». Конец этой нечистой власти, по Трубецкому, настанет лишь тогда, когда душа народов освободится от оков околдовавшего его плена». [4. - С.61]
А для того, чтобы победить в себе зверя, нужно, во-первых, смирение плоти, а, во-вторых, оно тем самым подготавливает грядущий мир человека. И в древнерусских иконах, по Трубецкому, выражены эти идеи. Так, аскетические лики святых могут показаться безжизненными, высохшими. «На самом деле, именно благодаря воспрещению «червонных уст» и «одутловатых щек» в них с несравненной силой просвечивает выражение духовной жизни. И неподвижность туловища святого, и сложенные крест-накрест руки, неподвижность позы, освященные канонами, только подчеркивает тот взгляд святого, выражение его глаз, что и составляет то высшее средоточие духовной жизни человеческого лица. «И именно здесь, пишет Трубецкой, - сказывается во всей своей поразительной силе то высшее творчество религиозного искусства, которое низводит огонь с неба и освещает им изнутри весь человеческий облик, каким бы неподвижным он ни казался... в древнерусской иконописи (таким образом) мы встречаемся с неподражаемой передачей таких душевных настроений, как пламенная надежда или успокоение в Боге». [3. С.334] И далее Е.Трубецкой подчеркивает, что в иконе духовная жизнь передается одними глазами совершенно неподвижного облика, есть ни что иное, как символически выраженная необычайная сила и власть духа над телом». [3. - С.335] И именно это сочетание совершенно неподвижного тела и духовного смысла очей, часто повторяющееся в высших созданиях нашей иконописи, производит, по мысли Трубецкого, потрясающее впечатление. [3. - С.335] И более того, неподвижность в иконах принадлежит лишь тем изображениям, где не только плоть, но и самое естество человеческое приведено к молчанию, где оно живет уже не собственною, а надчеловеческою жизнью. Но что особо подчеркивается Трубецким, что это состояние выражает собою не прекращение жизни, а как раз наоборот, ее напряжение и силу! [3. - С.336]

И далее, Трубецкой сравнивает русскую икону, например, с греческой. Он говорит, что от греческой иконы веет некой холодностью и отвлеченностью. И в этом отношении русская иконопись «согрета чуждой грекам теплотою чувства». Более того, именно в русской иконописи, в отличие от греческой, жизнь человеческого лица не убивается, а получает высшее одухотворение и смысл. В иконах русских (Трубецкой приводит пример лика «нерукотворного Спаса» или Ильи Пророка») «просвечивается одухотворенный народнорусский облик. Не только общечеловеческое, но и национальное, таким образом, вводится в неподвижный покой Творца и сохраняется в 
прославленном виде на этой предельной высоте религиозного творчества». [3. - С.337]

И еще об одном понятии, вводимом Е.Трубецким для лучшего понимания сути русской иконописи: это архитектурность и симметричность иконы. Трубецкой замечает, что подчинение живописи архитектурности обусловливается здесь не какими-то случайными или посторонними соображениями некоего удобства. Архитектурность иконы, по мнению автора, выражает одну из центральных и существенных ее мыслей. В ней, замечает он, мы имеем по существу живопись соборную, ибо в господстве архитектурных мнений над человеческим обликом, выражается подчинение человека идее собора, преобладание вселенского над индивидуальным. И, продолжает свою мысль Трубецкой, здесь человек перестает быть самодовлеющей личностью и подчиняется общей архитектуре целого». [3. - С.339] В иконе, таким образом, по Трубецкому, мы находим грядущего храмового или соборного человечества. Естественно, что такое изображение носит символический характер, ибо в действительности, соборности еще нет, а видим, по Трубецкому, только ее зачатки на земле. В действительности же мы видим нарастание раздора и хаоса (что, к сожалению, заметим, происходит и в наше время). И человечество не является единым храмом Божиим. Для осуществления подлинной соборности нужен «пост, и труд, и теснота, и всякие скорби» [3. C.339] И чтобы понять мысли, заложенные иконописцем в иконе, нужно особое сознание, ибо икона - больше, чем искусство. И чтобы икона с нами заговорила сама, придется ждать довольно долго, ибо нас от этого искусства отделяет огромное расстояние. И чувство расстояния, по Трубецкому, - это только первое впечатление, которое испытывается нами, потому что в строгих ликах иконы есть и то, что притягивает нас, влечет к себе и одновременно отталкивает. И чтобы понять икону, надо отказаться от целой большой линии жизни, от той, которая фактически господствует в мире. [3. - C.340] И пока мы не освободимся от всякой житейской пошлости, «сытой плоти» икона не заговорит с нами. «А когда она заговорит, она возвестит нам высшую радость сверхбиологический смысл жизни и конец звериному царству. [3. - С.340] И икона призывает нас к новой жизни, к высшей радости, которая изображается всей архитектурой храма, красочными узорами его причудливых орнаментов с фантастическими прекрасными цветами. Эта архитектура - проповедь. Она возвещает собою новый жизненный стиль, который должен прийти на смену стилю звериному, она представляет собою положительную идейную противоположность тому биологизму, который утверждает свое безграничное господство над природой и над человеком. Она выражает собой тот новый мировой порядок и лад, где прекращается кровавая борьба за существование и вся тварь с человечеством во главе собирается в храм». [3. C.342]

Статья Е.Трубецкого «Умозрение в красках» заканчивается, можно сказать, молитвою автора за мир на земле, за Россию: «пусть видят народы, что мир управляется не одним животным эгоизмом и не одной техникой. Пусть явится в человеческих делах и в особенности в делах России и высшая духовная сила, которая борется за смысл мира». [3. - С.353]

В работе «Два мира в древнерусской иконописи», Трубецкой как бы подводит итоги своего эстетического изучения иконы, открывшей нам целый пласт русской культуры, русского православного мировоззрения. Открытие иконы, пишет он, - дает нам возможность глубоко заглянуть в душу русского народа, послушать ее исповедь, выразившуюся в дивных произведениях искусства. В этих произведениях выявилось все жизнепонимание и все мирочувствие русского человека с XII по XVII век. Из них мы узнаем, как он мыслил и что он любил, как судила его совесть, и как она разрешала ту глубокую жизненную драму, которую он переживал. «И когда мы проникнем в тайну этих художественных и мистических созерцаний, открытие иконы озарит своим светом не только прошлое, но и настоящее русской жизни, более того - ее будущее. Ибо в этих созерцаниях выразилась не какая-либо переходящая стадия в развитии русской жизни, а ее непреходящий смысл». [5. - С.355]

И о еще одной особенности русской иконописи замечает Е.Трубецкой - в умении православного художника отделить красками два плана существования человека на Земле потусторонний и здешний. И как бы ни были многообразны эти краски, они всегда небесные краски в двояком, то есть в простои и вместе с тем символическом значении этого слова. Таким образом, «краски здешнего, видимого неба, получившие условное, символическое значение знамений неба и потустороннего». [3. - С.361] При этом художники были тонкими наблюдателями неба в обоих значениях этого слова. Небо здешнее открывалось их телесным очам; другое потустороннее они созерцали разумом, интуицией. Оно жило в их внутреннем, религиозном переживании». [5. - C.361] Потустороннее небо окрашивалось многоцветьем посюсторонних, здешних тонов, при этом каждый цветовой оттенок имеет в своем месте особое смысловое оправдание и значение. И если 
мы не всегда понимаем этот особый смысл, то это означает, подчеркивает Трубецкой, что мы потеряли ключ к пониманию «этого единственного в мире искусства»...искусства неизреченной красоты иконописной символики красок» [3. - C.361] Особенно поразила воображение Е.Трубецкого шитая икона Св.Софии XV в., и другие иконы Софии, но все они имеют одну общую черту: все они изображали сидящую на престоле Софию на темно-синем фоне ночного, звездного неба. Это, по мнению, Трубецкого - «пурпур Божьей зари, зачинающейся среди мрака небытия; это восход вечного солнца над тварью, ибо София - то самое, что предшествует всем дням творения». [3. - C.361]

Размышляя над тем, как художник создавал такое творение, Трубецкой приходит к мысли, что это вряд ли было сознательное размышление. Он считал, что пурпур Софии был найден скорее озарением творческого инстинкта, каким то мистическим сверхсознанием иконописца». [3. C.366]

Е.Трубецкой критикует такое отношение к иконе к ее сюжетам, как некое проявление языческой культуры в творчестве иконописцев Средневековья. Он подчеркивает, что разница между языческим и православно-христианским мирочувствованием иконописца в том, что иконописец видит эти пурпурные персты не в здешней, а в предвечной заре и относит их к небу потустороннему и таким образом пурпур в самом существе своем остается именно как одухотворяющее его начало. И в традиции русской иконописи пурпур знаменует собой соприкосновение солнечного света со тьмою, то есть тут символика несколько иная, чем в язычестве.

Свое исследование русской иконописи Е.Трубецкой продолжает, вскрывая более глубинный пласт «умозрения в красках» психологический, то есть обращается к тому внутреннему миру человеческих чувств и настроений «солнечного откровения», где «солнечная лирика светлой радости» переплетается с мотивом величайшей в мире скорби - с драмою встречи двух миров. Так в иконе Благовещения выражается народнорусское понимание того праздника, о котором радуется «вся тварь вместе с человеком - это праздник прилета вешних птиц, ибо согласно народному поверию, «и птица в этот день гнезда не вьет». [3. - С.369] И поразило Трубецкого то, как мог русский иконописец привнести грустному русскому северу эту воистину благую весть о невиданной и неслыханной у нас радости света? И отвечает, что внимательно всматриваясь в изображенное на иконе, открываем в ней самую парадоксальную черту русской иконописи.
Оказывается, что радужное невиданное сияние есть сияние, праздник для глаза. А позы евангелистов на иконе не видят этого сияния смотрят, но не видят», ибо все евангелисты погружены в слух и в записывание услышанного. А евангелист Иоанн не пишет, а диктует своему ученику Прохору, поза которого - есть поза человека отдающегося откровению. И он (Прохор) всей своей позой выражает безграничную, слепую покорность. По мнению Трубецкого, Прохор, его покорность есть как бы «человеческое эхо апостола». «Но не в одной этой покорности выражается психология человеческой души, переживающей процесс откровения». Высшим обнаружением этой психологии покорности, по Трубецкому, является «тот внутренний слух, которому дано слышать изреченное». [3. - C.371] И этот слух иконописцами передается по-разному. Часто это поза человека, углубленного в самого себя и как поворот к невидимому, отсюда у евангелистов потустороннее выражение очей, которые не видят окружающего. [3. - C.371]

Но так или иначе, - подчеркивает Трубецкой, - в иконописи отражается та борьба двух миров и двух мирочувствий, которая наполняет собою всю историю человечества. С одной стороны мы видим миропонимание плоскостное, все сводящее к плоскости здешнего. А с другой стороны, выступает мистическое мирочувствие, которое видит в мире и над миром великое множество сфер, великое многообразие планов бытия и непосредственно ощущает возможность перехода из одного плана в другой. [3. - С.375] И, возможно, самая трогательная, самая привлекательная черта иконописных изображений, по Трубецкому, заключается в любовном, глубоко христианском отношении к тому несчастному, который бессилен подняться духом над плоскостью здешнего мира. [3. С.376]

Оценивая древне-русское религиозное искусство иконописи, невольно приходишь к мысли, что мы когда-то имели и что мы в ней утратили, поэтому, подмечает Трубецкой, мысль о том, что этот бессмертный памятник духовного величия относится к дальнему нашему прошлому, заключает так же в себе что-то бесконечно тревожное для настоящего. [3. C.380]

Но не только живописное искусство волновало кн.Е.Трубецкого. С детства в семье Трубецких музыка играла чрезвычайно большую роль. Так, близким другом семьи Трубецких был А.Рубинштейн. В Ахтырке, в усадьбе Трубецких, музыка постоянно звучала в лучшем исполнении. Впоследствии Е.Трубецкой писал, что вся Ахтырка была симфонией, а его философия и философия брата Сергея явилась дочерью 
музыки. Музыка как единящее и гармонизирующее начало формировало «музыкальную душу», которая воспринимала жизнь не только зрением, но и «внутренним слухом». Музыка пробудила интерес к высшим планам бытия. [5. - С.8] Огромное впечатление и глубокое переживание испытал Е.Трубецкой при прослушивании десятой симфонии Бетховена в исполнении симфонического оркестра под управлением Антона Рубинштейна. Под влиянием гениального творения Бетховена в душе Е.Трубецкого происходит «неожиданное откровение бытия Божьего. Трубецкой так описывает свои переживания музыки. Сначала «в поразительном скерцо... душа пытается найти выход из густеющей темноты. Откуда - то раздается тривиальная мелодия буржуазного веселья...[Но] долой это недостойное мнимое освобождение! В душе не должно быть места для мещанского самоудовлетворения. И снова диссонансы и хаос. Космическая борьба звуков, наполняющая душу отчаянием... И внезапно... раздается величественный призыв с высоты, из другого плана бытия. Из бесконечного далека «пианиссимо» слышится до сих пор неслышанная мелодия радости... звуки растут, расширяются, приближаются. Это уже не только обещание далекого будущего... И вдруг вы возноситесь выше звезд, выше мира, выше всей скорби существования...». [6. - С.10] Под влиянием прослушанной музыки как бы довершаются духовные искания философа, в ходе которых он обрел веру, как источник высшей радости, эстетического наслаждения от наполненности бытия, божественного бытия.

Размышляя над вопросом о возникновении музыки, Трубецкой говорит, что как для человека, так и для животного, в отличие от мира растительного, где существует, по его мнению, только пассивное воспроизведение солнечного луча в пестром радужном покрове, животное же отвечает на него «откликом живой радости». И животное царство в отличие от беззвучного царства растительного, есть мир звучащий. Подачей голоса в ответ восходящему солнцу животное заявляет себя «не пассивным проводником света, а самостоятельным глашатаем и участником Божьего утра». [8. C.177] И далее Трубецкой заявляет, что в радости утренней симфонии ... есть новое и великое откровение всеединства. Музыканты давно подметили сродство между звуковой и световой гаммой. Слушая воспроизведение птичьих голосов в «Пасторальной симфонии» Бетховена или в «Зигфриде» Вагнера, подчеркивает Е.Трубецкой, - мы ясно видим игру солнечных лучей в густой зелени лесов». [8. C.177] Но что важно в рассуждении автора, так это то, что это сродство света и звука все же не есть тождество. Поэтому голос, который вторит солнцу не является его явлением, а сочувствующее ему действие и славословие другого. «Он не повторяет откровение творящего света, а как бы соучаствует в нем, дополняет его, превращая световую радугу в симфонию». [8. C.178] Но, по мнению Трубецкого, - в животном мире нет самого существенного, о чем вещает симфония, так как созвучие и согласие в ней оказывается поверхностным, призрачным. Поэтому-то в чувствующем животном царстве осуществляется всеобщая борьба как отвратительное проявление алчности и ненависти победителей и страданиями побежденных. Когти и зубы хищника, приспособленные к тому, чтобы терзать живое тело, представляют собою воплощенное отрицания согласия и сочувствия. А так как современный человек еще до конца не победил в себе зверя и действительность нашей жизни бесконечно далека от достижения подлинного созвучия и сочувствия, «в ней симфония лишь слабое отражение потустороннего, отблеск грядущего, отдаленного, как звезды, мерцающего в высоте». [8. - С.179] Таким образом, полнота Божьего дня может явиться, по Трубецкому, лишь в полном пробуждении твари, ибо в предвечном замысле Софии мир - не пассивная среда, не страдательное орудие откровения, а вселенское дружество. И вместить в себя это вселенское откровение может только высшее существо, которое не только преломляет свет, не только к нему влечется, не только ему сочувствует, но и сознает». [8. - С.180] Именно человек с помощью своего сознания способно подняться над непосредственными психическими переживаниями в область «абсолютного сверхпсихического смысла». [2. - С.181] Ибо только человек может подняться над непосредственным психическом переживанием и влечением в поиске безусловной правды о сущем и должном. В силу этой своей способности человек - единственное на земле существо, могущее принять откровение мысли безусловной. И это не только способность человеческого ума, ибо в совести объединяется и ум и сердце. В ней выражается духовный подъем всего человеческого существа. И, наконец, именно в силу своего подъема к Безусловному над ощущением, над чувством, над аффектом человек может сочетаться с Богом не узами инстинктивного влечения, а теми узами сознательной духовной солидарности, которое преображают и жизнь душевную». [8. - С.181] И далее Трубецкой излагает свой вариант идеи «всеединства». Человек, - говорит он, - «носитель мысли вселенской, всеединой по форме, ибо всякий акт его сознания есть соотнесение сознаваемого к всеединой истине, объемлющей 
все. Это сознание представляет собою всеединство в возможности; поскольку же оно познает и вмещает в себе истину, оно становится всеединством в действительности. Так осуществляется в человеке образ и подобие того всеединого сознания, которое держит в себе все и есть истина всего. Это - земное подобие Вседержителя». [8. - С.182] Так осуществляется в действительном единстве ИСТИНА, ДОБРО И КРАСОТА.

Свое понимание идеи всеединства Трубецкой противопоставляет «эстетической теодицее» Августина Блаженного. Согласно учению Августина, зло - необходимая эстетическая антитеза добра в мироздании. Зло, говорит Августин, - в мире необходимо как диссонанс в музыке, который составляет необходимый элемент в гармонии целого, или как тень в живописи: ложась рядом со светом, тень составляет необходимое условие красоты картины как целого». Возражая против такой постановки вопроса о «встроенности» зла в общую картину мира, Трубецкой пишет: «нетрудно убедиться в том, что и этот эстетизм содержит в себе кощунственную мысль о зле как о необходимом украшении созданного Богом мира. В этом качестве зло якобы нужно Богу, нужен грех, потому что он своим контрастом делает добро более рельефным, нужно и страдание, как эстетический контраст к блаженству. [И получается], что вместо того, чтобы быть «оправданием» Богу, такая теодицея есть тяжкое против Него обвинение, ибо она представляет Его жестоким мучителем, для которого страдания твари служат предметом эстетического наслаждения. Такая августиновская теодицея, по Трубецкому, которая вносит роковое раздвоение в предвечный божественный план, носит, на самом деле, на себе очевидные следы не вполне побежденного манихейского влияния. [8. - С.120]

Если признать, что царство зла возникло вопреки предвечному замыслу, как утверждается в христианстве, как временное торжество ненависти, из-за несовершенства человека, наделенного свободной выбора. Тогда получается, «что вместо дружества» между Богом и тварью возникает совсем другое: «тварь не захотела» и весь мир превратился в кромешный ад. И вместо «всемирного дружества» в нем царствует нескончаемая оргия убийства и взаимной ненависти. [8. - С.121] Итак, свобода воли человека - это хорошо, но если человек никогда не захочет повернуться к Богу, тогда что, конец света?

Так, например, большевики утвердили «звериное царство», так как, по Трубецкому, сочетались не с Богом, а со зверем и посему этот путь ведет к смерти человечества. Причиной большевизма он считает «угасание духа». Утраченные духовные ценности были заменены идолами: поклонение «золотому тельцу» породило между людьми взаимную ненависть и вызвало войны. Но так поступили не только большевики. И сам Трубецкой говорит о том, что само государство, его существование в мире есть угроза человечеству. «Государство стремится стать «смертным богом» для человека, а это ведет в конечном счете, к утрате человека. Государство порождает, субсидирует «нужных» ему людейпалачей, шпионов, проституток, то есть таких людей, которые способны на всякие мерзости». [6. - C.11]

Работу «Смысл жизни» Е. Трубецкой написал в начале XX в. Может что-нибудь изменилось с тех пор, люди «одумались» и повернулись к построению гуманистического, безъядерного мира? Было такое «настроение» в конце XX в. Возникли мысли, желания и некоторые объективные предпосылки к этому повороту. Вся надежда была на XXI век. И что же? В 2011 г. мы вынуждены констатировать о повороте, но совсем иного плана. Вместо всеобщего мира на планете получился такой всплеск локальных, а по существу своему глобальных войн. Возникли теории «Золотого миллиарда», вахобизм, терроризм, наносящий удары всему миру, бъющие в самое сердце человечества, так как действуют террористы изза угла и убивают безвинных людей. Например, школа в Беслане, взрывы в Московском метро, другие зловещие вещи. И главным возмутителем этой всемирной вакханалии зла, оплотом его выступают США. Это они подхватили теорию Троцкого об «экспорте революции», подвели новую теоретическую базу - и этот экспорт «оранжевых революций» охватил весь мир войны на Балканах, Афганистан, Ирак, Украина, Грузия, Киргизия, Ливия и т.д. Список этот можно продолжить. Суть этих мер якобы «наведения порядка» состоит в том, чтобы установить в этих странах власть, послушную США и всему Северо-Атлантическому блоку. Таким образом, кучка негодяев желает покорить весь мир! Идея мирового господства от Наполеона к Гитлеру протягивается теперь к мировому жандарму - США. И совсем по-иному перекраивается теория и практика «наведения порядка»: раньше бедные выступали против богатых, которые угнетали бедных, эксплуатировали их. Теперь картина кардинально изменилась: богатые выступают против бедных, то есть на смену экономической эксплуатации пришло политическое завоевание, господство, военное подавление трудящихся. Так, в современной России существует настоящий геноцид по отношению к населению страны. За годы «перестройки», а по-сути, «верхушечной 
революции», утверждения антинародной власти умерло, погибло около 8 млн. населения. За один только 2010 г. население России уменьшилось на 0,5 млн. человек! А Чубайс - американский выкормыш один своей «прихватизацией» обездолил все население страны, ограбил накопленные в обществе общественные богатства. Он нагло и цинично объявил, что они (т.е. власть) не пришли к единому мнению какую численность населения оставить в России 90 или 70 млн. человек! До какой подлости нужно дойти человеку, чтобы против своего народа пойти на такие беспрецедентные меры! Хочется задать всем нам вопрос: до каких пор мы будем терпеть то зло, которое творится в мире? Патриарх Кирилл в своем обращении к народу по случаю праздника Воскрешение Христа, поздравил россиян и посетовал, что зло все еще царствует в мире, но не ответил почему? При такой расстановке классовых сил на планете ответ может только один: силы зла объединились быстрее сил добра и свою оборону они держат пока крепко. Возможно, люди поймут в конце концов, что и добро должно быть с кулаками, а конфронтация в мире грозит гибелью всего человечества.
О Е.Трубецком, о его философском творчестве можно сказать словами самого же Трубецкого, которые он изложил в своей статье «Старый и новый национальный мессианизм» об апостоле Иоанне, что он наметил тот путь, которым нужно идти, чтобы проникнуть в сущность русской религиозной мысли... И прежде всего, нужно нам отрешиться от русского национального мессианизма. Тогда только живые черты нашей национальной физиономии перестанут растворяться в Абсолютном и мы приобретем нашу подлинную народную душу. И как завещание Е.Трубецкого, звучат его слова о том, что один и тот же закон действует и в жизни отдельных людей, и в жизни нардов. Чтобы сохранить свою душу, народ должен не возлюбить, а возненавидеть ее в мире сем». [7. C.323] И «чем мучительнее ощущение царствующей кругом бессмыслицы,подчеркивает Е. Трубецкой,- тем ярче и прекраснее видение того безусловного смысла, который составляет разрешение мировой трагедии». [8. - С.7]

\section{References:}

1. Tsent.Bezanson A. (2010) Forbidden image. Moscow: MIK, 1999. - p.151 // See Polovinkin.: SM Prince Troubetzkoy life and career. - Moscow: Synaxis. 2010. pp.157.

2. Bunin IA (1967) Coll. Op. in 9 volumes, v.9 Moscow, 1967, pp.221.

3. EN Troubetzkoy (2005) Speculation in the paint // E.Trubetskoy meaning of life. - Moscow: "Canon +" ROOI "Rehabilitation". 2005.

4. EN Troubetzkoy (1991) Savage kingdom and the coming revival of Russia "- Rostov-on-Don, 1919 // See.: Kuban, 1991, № 2.

5. EN Troubetzkoy (2005) Two worlds in ancient iconography. // EN Troubetzkoy The meaning of life. - Moscow: "Canon +" ROOI, "Rehabilitation", 2005.

Available: (Accessed: 10.02.2016).
6. SM Polovinkin (2010) Prince E.N.Trubetskoy life and career. Biography. - Moscow: synaxis 2010.

7. Levitsky SA (1981) Essays on the history of Russian philosophy and social thought. Frankfurt, 1981. T. II, pp.10.

8. EN Troubetzkoy (2005) The meaning of life. Moscow: "Canon +" ROOI "Rehabilitation". 2005. pp.436.

9. VV Sapov (2005) Prince E.N.Trubetskoy. Essay on the life and creativity. // EN Troubetzkoy The meaning of life. - Moscow: "Canon +" POOH "Rehabilitation", 2005.

10. B. Friedland (1988) Life in Art // enter. Article. Sat.: IS Turgenev in the memoirs of contemporaries. - Moscow: "The Truth", 1988, pp.7

et al. 